\title{
TRANSFORMATIVE PRINCIPLES AND STRATEGIES OF EDUCATION IN CHINA DURING THE CULTURAL REVOLUTION
}

\section{DHARMA BAHADUR THAPA}

Assoc. Prof., Department of English, Birendra Multiple Campus, Bharatpur, Nepal

\begin{abstract}
This article attempts to explore the aims, principles and strategies of education adopted in China during the period of Proletarian Cultural Revolution which lasted for a decade (1966-1976). More than four decades have passed since its formal annulment, it is still generating strong opinions for and against. Some approve it for its agenda of radical social and educational transformation whereas others critique it as source of social, economic and political disasters in the country. Instead taking side, this paper attempts to present the theoretical premises and practices adopted in that period by using the authentic documents published by the Chinese Communist Party and the government. It uses the articles from Peking Review (which later became Beijing Review) of the same period as the primary sources, for it is the authoritative organ of the party. The analysis of these and other materials leads the writer to the conclusion that the education of that period was trial based and strictly guided by Marxist Leninist socialist principles and in many ways marked a radical departure not only from the old Chinese system of schooling but also from the contemporary pedagogic practices around the world.
\end{abstract}

KEYWORDS: Anti-Bourgeois, Productive Labour, Socialist, Trial Based

Received: Aug 01, 2020; Accepted: Aug 21, 2020; Published: Dec 10, 2020; Paper Id.: IJELOCT20205

\section{INTRODUCTION}

\section{Marxist Approach to Education}

Effectiveness of school education is a never ending topic for discussion among scholars, professionals, politicians and the general public. Almost all of such concern is limited to micro level components of education like class room activities of teachers and students, curricula, textbooks other teaching materials, the percentages of passes and fails and of marks students score and its affordability in terms of financial strength to the deprived population. We very rarely come across discourse on the macro level subjects like the fundamental purposes and its transformative role in the society as a whole. This article attempts to explore the role of education can play in the radical transformation of a society by foregrounding the orientation of education system in China during the world famous Cultural Revolution that lasted from 1966 to 1976. Many people have little idea about how China during the Mao era carried out its education policy and differed from the practices prevalent in the old China and the capitalist world. The knowledge they have is influenced by the anti communist propaganda which presents the revolution as the synonym of disaster.

Beginning with some of excepted definitions of education and then discussing the aim of education as designated in Marxism, the article addresses the issues like Marxism and education, Mao's education principle, Cultural Revolution and values it stressed. It briefly introduces the Cultural Revolution and the principles which guided it. It explains the strategies and methods that were adopted in education during the period. It uses the 
documents published in Peking Review (later Beijing Review) as the materials for study because it is the authentic party or government publication. Study on such topic will be relevant to understand what the alternative form of education can be.

According to Socrates main function of education is to dispel error and to discover truth (qtd. in Aggarwal 1995, p. 5). In other words, education has something to do with gaining knowledge. On the other hand Aristotle opines that education helps create a sound mind in sound body ( $\mathrm{p} 4$ ). This definition highlights the intellectual and physical function of education. The aim of education is, therefore, to produce morally rational and physically healthy citizens. The views of these philosophers still guide theories of education.

Marxist ideas on education can be found in various works of Marx and Engels. They believe that education functions as one of many components of superstructure which is founded on socio-economic base. As a radical theory, it takes education as an instrument of revolutionary transformation of society which is founded on exploitation of labour by capital. In "Thesis on Feuerbach" Marx (1977), advances that "the philosophers have only interpreted the world, in various ways; the point, however, is to change it" (p.15). Education in Marxist tradition is not only a process of getting knowledge; it is an instrument to change the world including society and individuals. It admits that education cannot be independent of classes, class interests and corresponding ideologies. Therefore, system of education is guided by the interest of the ruling class (the bourgeoisie) from whose influence Marxism aims to "rescue" it (p. 124). In "Principles of Communism" Engels (1977) proposes that nation and national institutions bear the expense of care and education of children and education is combined with production ( p.91). Lenin also stresses on the need of close relation between education and productive labour (qtd. in PR 1976, No.10 p.9). Therefore, by proposing the combination of education with productive labour, Marxism takes education as an instrument of class struggle and social change.

\section{Mao's Ideas on Socialism and Education}

Marxism is a dynamic philosophy. It has been developed, updated and enriched with social and historical changes to address newer challenges. Marx and Engels propounded their theory analysing the history of societies in terms of class struggles. They could not witness the successful socialist revolutions in their life time and did not have to face practical problems of education. However, Marxist thinkers and practiceners after them have advanced ideas and concepts about the contents, characteristics and implementation of education in a socialist society. Mao, more than any other Marxist philosophers, has laid down principles and issued directives in his works about the role of education in socialism. He believes that education is a component of the whole socialist revolution. According to him class struggle continues in socialism in the political and ideological spheres. For this reason he initiated the Proletarian Cultural Revolution (19661976) in China. Despite being a political movement, the Cultural Revolution has multiple dimensions. It aimed at revolutionizing the culture of the whole Chinese society according to the road charted by Marxism. Education during the CR was radically different from the system that existed before, in China and anywhere. Mao (1977) advances:

In China, although socialist transformation has in the main been completed as regards the system of ownership. . . [C]lass struggle is by no means over. The class struggle between the proletariat and the bourgeoisie ... and the class struggle between the proletariat and the bourgeoisie in the ideological field will still be protracted and tortuous and at times even very sharp. The proletariat seeks to transform the world according to its own world outlook, and so does the bourgeoisie. (p. 409) 
Here what Mao stresses is mere socialist system of collective ownership does not guarantee socialist development because classes and class struggle exist in social and ideological realms. According to him the bourgeoisie and the proletariat, as antagonist classes, try to change the society according to their world outlook and class interests. This means that a socialist society is full of possibilities of reversal to capitalism if the proletariat does not wage struggle against the bourgeois ideas and beliefs.

The role of education, as a component of superstructure, in the socialist transformation has philosophical backing. Mao's proposition on the dialectical relationship between the base and the superstructure throws light on the role of education in promoting the socialist ideology and culture. In his philosophical essay Mao (1971) advances: True, the productive forces, practice and economic base generally play the principal and decisive role . . in certain conditions, such aspects as the relations of production, theory and the superstructure in turn manifest themselves in the principle and decisive role ( p.116). In some circles Marxism is misinterpreted as 'economic determinism/reductionism' for its proposition that socio economic condition (base) determines beliefs (superstructure). But Mao advances the proposition that the relationship between them is not mechanical but dialectical. As a whole, base is decisive. But in certain conditions, superstructure also plays the decisive role. As already mentioned economic production forms the base whereas culture, religion, law, morality, political theories, ideas and education comprise superstructure. Once again Mao opines that education system, as a component of superstructure, can promote or obstruct certain social system. For example if there is bourgeois education in a socialist system, it promotes bourgeois values and inhibits socialist progress. His essay (1958) "Principles of Educating Youth," emphasizes that young people should be encouraged to become close to the workers and peasants and serve them. For this reason Mao gave an importance to the type of education which could inculcate and promote socialist values in the younger generation who do not know the suffering of the old society. Mao believed that only the party and state attempts would not suffice to prevent the restoration of capitalism. The participation of the masses was also necessary. Mass education was a part of this revolutionary awareness

He (1977) stresses:

[w]e must fight against the tendency to ignore politics, it won't do to confine oneself to politics and have no technical or professional knowledge . . . in all trades and professions should strive to be proficient in technical and professional work, turn themselves into experts and become both red and expert. It is wrong to talk about becoming expert before becoming red, which is tantamount to being white before being red. (p. 489)

So an educated person in the Maoist sense is one who is imbued with proletarian revolutionary consciousness and knowledge or expertise in the given field. Being red is not optional but the matter of prime importance because if one lacks right/red political orientation, one is bound to be guided by wrong or bourgeois ideology. So combination of both will enable one to contribute to the cause of socialist revolution and construction. It is further explained:

There are still distinctions in China today between town and country, between workers and peasants and between mental work and physical labour. To eliminate these differences requires the efforts of everal generations. The young people today must do their utmost and make their contribution ... The country is the classroom for educated youths to get class education. . . They can learn what class oppression and class exploitation are, understand the superiority of the socialist system, enhance their consciousness in 
remoulding their world outlook and really become one with the working people in ideology and sentiment. (Peking Review 1976, No. 2 p.12)

So, the purpose of education is to produce the remoulded manpower which contributes to the formation of a society without distinctions and privileges. Students should adopt socialist values and consciousness, identify with the working class and remould their outlook. Education during the Cultural Revolution (the CR hereafter) was guided by these aims.

\section{Debates and Controversies over the Cultural Revolution and its Role in Education: A Review}

Very few topics have elicited so much debates and controversies as has done the Chinese Proletarian Cultural Revolution. It is common to present it as the most destructive and misguided event. The post-Maoist Chinese leadership follows suit. Most of the evaluations of the CR are ideologically motivated. Communist Party of China (1981) formally denounced the CR "catastrophe to the Party, state and the whole people" (Beijing Review, 1981, No. 27 p. 22). Li and et al. (2020) point out that during the $\mathrm{CR}$ "the education standard declined" and the education of the "next generation" was also disrupted (https/doi.org/10. 1080/). Xuan (1981) takes it as "a nightmare for every just-minded Chinese" (BR 1981, No. 44 p. 20) and having no economic and political basis (p. 22). However, Saywell (1980) opines:

Although the academic quality was sacrificed, some very real progress appears to have been made in achieving universal primary education in all but the most remote areas, and getting a higher percentage of the nation's youth, particularly from worker/peasant backgrounds into some area of secondary education. Schools were relocated at the basic production units, more schools were established, attendance rules were made more flexible . . . to correspondence with the agricultural season, financial aid was given[sic] poorer children. . . Enrolment in middle schools almost quadrupled ... (pp 4, 5).

Dongping (2000), on the other hand, sees the CR as empowering ordinary people to challenge "the tight control over political resources by party leaders at different levels" (p. 54) and contends that it resulted in big achievement in China's rural development of education (p.134).

Instead of passing positive or negative judgements on the CR and its role in education in China, the purpose of this article is to present the theoretical premises, educational policies, strategies and practices adopted during of the CR so that readers can judge them of their own.

\section{Education in China during the Cultural Revolution}

"Decision of the Central Committee of the Chinese Communist Party Concerning the Great Proletarian Cultural Revolution" formulates the purposes and formulates the strategies of the Great Proletarian Cultural Revolution (GPCR). It was adopted on August 8, 1966 ( $P R$ 1966, No. 33, p.6). It defines the CR as "a great revolution that touches people to their very souls" (p.6). It was directed against "four olds". It elaborates:

Although the bourgeoisie has been overthrown, it is still trying to use the old ideas, culture, customs and habits of the exploiting classes to corrupt the masses, capture their minds and endeavour to stage a comeback. The proletariat must do just the opposite; it must meet hard-on every challenge of the bourgeoisie in the ideological field and use the new ideas, culture, customs and habits of the proletariat to change the mental outlook of the society. (PR 1966, No. 33 p. 6) 
In a nutshell, the GPCR was the conscious struggle of the proletariat against the bourgeoisie in the "ideological field" and its ultimate aim to instil new proletarian culture and "change the mental outlook of the society" accordingly. Its immediate target was people in power "taking the capitalist road" (p.8).

In education the movement targeted "the bourgeois academic "authorities"” ( $P R$ 1966, No. 33 p. 6), for they exercised monopoly over the system. The major task of the CR was "to transform old educational system and the old principles and methods of teaching" (p. 8) because it served the interests of the bourgeoisie. It advocated "education serving proletarian politics and education being combined with productive labour" so that students "develop morally, intellectually and physically" and "become labourers with socialist consciousness and culture" (p.10). Serving proletarian politics was the main purpose of education during the CR. When one realises that education in any society inherently contains the class orientation, this motto does not sound odd. To get this aim fulfilled, students had to take part in productive labour as a part of education. This would enable them to assimilate with the working class and adopt the proletarian outlook and values. Getting education was more than completing the given academic courses, gaining certificates of the degrees and expertise which would qualify the candidate for certain official position. The tendency to get education "in order to become an official" was criticized (PR 1969, No.14, p. 11). The touchstone was whether one has transformed practically in real life or not. If one is imbued with socialist consciousness and morality alongside expertise, one is liable to be qualified as educated.

\section{Values Emphasized and Strategies Used in the Implementation of Socialist Education}

Although communist seized the state power in 1949 and Mao was the principle architect of the revolution, China implemented old form of Education until 1966. Mao's principles, policies and directives started to be implemented as guidelines only during the CR. He advanced that students should not limit themselves to the classroom study but should also learn "industrial work, farming and military affairs" (qtd in PR No.7 1969, p. 4). He proposed that "the length of schooling should be shortened, education should be revolutionized, and the domination of our schools and colleges by bourgeois intellectuals should not be tolerated any longer" (qtd. in PR 1969, No. 39, p. 9).

One of the strategies to implement socialist principles of education was to ensure the working class leadership and orientation. Mao emphasized on working class leadership as the precondition for running academic institutions so that the correct orientation could be ensured (qtd. in $P R$ 1969, No. 7, p. 3). To implement proletarian, cultural courses were given prominence in place of "intellectual courses" of the past (PR 1970, No 39, p. 14). It was thought that "intellectual courses" served the bourgeois politics and encouraged students to seek "fame and position" (p. 14). Tsinghua and Peking Universities selected students from among the workers, peasants and soldiers and set up various specialized classes while carrying on a deep going revolution in education ( $P R$ 1970, No. 40, p. 6). These students came with practical experiences in their respective fields and provided chances to learn for those who have only theoretical knowledge. This also helped narrow down the gap between workers and intellectuals. Tsinghua University also introduced worker- teachers in teaching. An article published in PR 1971, No. 4 mentions:

Under the guidance of Chairman Mao's proletarian line, Tsinghua University has selected a number of full or part-time teachers from workers in the forefront of the three great revolutionary movements- class struggle, the struggle for production and scientific experiment. These worker-teachers . . . have a high level of political consciousness and practical experience in production. They give prominence to proletarian politics, dare to blaze new trails and criticize the bourgeoisie. (p. 7) 
Using workers as teachers, who are politically conscious and professionally experienced in the respective fields was something new. This was introduced because in the old education system teachers only lectured on theories and completely disregarded the social class which education has to serve (ibid p.8). Students were taken to factories and enterprises to make investigation and study among the workers and revolutionary cadres (p.9).

Not only students but faculty members were also encouraged to integrate with workers so that they can remould their world outlook and adopt the proletarian revolutionary outlook. Peking Review (1973, No. 8) reports:

In the last few years, the overwhelming majority of the more than 2,000 faculty members in Tsinghua, .

. . integrate themselves with the workers and peasants, have gone to factories farms and villages for six to twelve months tempering through physical labour. Their eagerness to be re-educated by workers, peasants and soldiers and remould their world outlook in the course of the the three great movements-

class struggle, the struggle for production and scientific experiment- has enabled them to raise their consciousness ... (p.10)

This kind of integration encouraged both sides to learn from each other. Workers could learn the theoretical knowledge of the intellectuals and the intellectuals, in turn, would learn and energize themselves with the fresh practical experience and revolutionary spirit of the workers. Moreover, they would learn to respect the working class and their contribution in the socialist development and revolution. Each was complementary to the other in the overall development of the level of education.

Theory oriented teaching was criticized as "idealist apriorism which separates theory from practice" and a synthesis of "teaching, research and production" was emphasized (p.10). In old method of teaching students had to parrot the drills and formulae instructed by the teacher. There was no place for student's creativity and initiative. This was called "injection method" which they wanted to abolish (p.11). The new approach:

[T]ried out a teaching method which incorporated enlightenment, experimentation and research and actively advocated self-study. They distributed teaching materials, spending only a little time on lectures ... left rest of the time for them to study problems, text books and reference books and make experiments or carry out social investigation and class room discussion. This livened up the studies. (p. 11)

Therefore, as one can see, much space is left for the students' initiative, creativity and hard work.

Attempts were made to depart from the old method of enrolment, evaluation and examination. Tsinghua University carried out "the principle of enrolling students from workers, peasants and soldiers with practical experience" because " the old method which used to decide the fate of an applicant entirely according to marks" only reflected "book knowledge obtained through learning by rote" which could not reflect "the applicant's all round character" (PR 1973, No. 9 p. 15). Instead of certificate, bookish knowledge or marks obtained through memorization, class affiliation and practical experience were decisive in the process of enrolment.

Examination was taken as a means "to promote study" not "a test of memory but the power of reasoning" ( $P R$ 1967, No. 47 p. 11). Traditional method of mechanical repetition of teaching material was opposed and students were encouraged to be original and creative (p.11). The reason to undertake a departure from the old method of examination was stated in these terms: 
The old system treated students like enemies and made sudden attacks upon them, trying to catch them unawares. This must be changed. This does not mean, however, the examinations are to be abolished. A more lively system of testing is called for: topics should made public beforehand and the students should be allowed to study and answer questions by referring to whatever books they need, so that they can concentrate on training their ability to analyse and solve questions. (PR 1973, No. 8 p. 12)

Another method used to familiarize students with the working class living and inculcate in them the working culture was to encourage them to go to the countryside and work with peasants for certain time. Mao stated that "it is highly necessary for young people with education to go to the country side to be re-educated by the poor and lower middle peasants" (qtd. in $P R$ 1974, No. 31, p. 13). This became a trend for students to settle and take part in productive labour as a part of learning. It is reported that in Chuchou, a medium sized city in central-south China, has settled some 8,000 educated young people in groups, on the farms, timberland or tea gardens run by people's commune (p.13). It is reported that "approximately 10 million middle school graduates have gone to rural and mountainous areas to integrate with the workers and peasants " ( $P R$ 1975, No. 6, p. 5). Students were enrolled from the working class and after they get educated, they go back to the people to work like one of them and adopt their culture and ideology. This was called the system of coming from and going back to commune which reformed "the old educational system and pedagogical principles and methods" (PR 1975, No. 7 p.13).

During the CR, attempts were made to narrow down the gap between the manual and intellectual jobs. The logic was that the old type of education created antagonism between workers and intellectuals. Therefore factories were assigned to run colleges. Chiao (1975) argues that such colleges facilitated to "promote integrating education with productive labour" (p.17) and helped to reduce "the antagonism between mental and manual labour" (p.19).

They experimented with many newer techniques in education to make a radical departure from the existing conventions which could hamper socialist education. Various types of schools and classes were run to suit the conditions and needs of the learners belonging to diverse locality, ethnicity, geography and professions. Shih (1976) explains that during the CR teachers and students "broke through the confines of the university, integrated with the workers and peasants and vigorously launched a revolution in education. Open door education is one of the new things emerging from this revolution (p. 16). Mobile schools were run to "serve the herdsmen living widely in scattered places" of Tibet (PR 1971, No. 35 p. 27). "Politics, minority nationality languages and literature and art" were taught and "tuition fees, living expenses and medical costs are all paid by the state" ( $P R$ 1972, No. 10 p. 4). Mass physical training and sports activities were taken as an integral part of education "to train prospective athletes for the country" ( $P R$ 1972, No. 14 p.13). Criticizing the bourgeoisie, mass work, militia training and cultural activities were also part of schooling ( $P R$ 1972, No. 19 p. 5). There were "spare time night schools for peasants" for general education ( $P R$ 1973, No. 23 p. 18). Following Mao's instruction all agricultural colleges were moved to the rural areas ( $P R$ 1976, No. 10 p.6).

The most important achievement of education system in China during the CR was claimed to "break the monopoly of bourgeois intellectuals and establish working class leadership" (PR 1976, No. 10 p. 6). With the death of Mao in 1976, the Cultural Revolution came to an end. The practice of "quality first" and priority on academic degrees was restored at the cost of class background, practical experience and revolutionary orientation (BR 1981, No. 46 p.20). 


\section{CONCLUSIONS}

The study based on the materials published by the Chinese Communist Party during and after the Cultural Revolution leads the researcher to conclude with certain dominant themes about the orientation of education during that era. First of all, it shows that education was not taken as a medium of simply getting knowledge or expertise on something. It was taken as an instrument of socialist revolution and raising the revolutionary consciousness of the whole population. For this purpose, ideas propounded by Marx, Engels, and Lenin, more specifically of Mao were taken as guiding principles and legitimizing ideology. Although cognitive aspect was important, much emphasis was laid on the transformative role of education.

The system of education was very much goal directed. Going beyond the aim of producing red and expert manpower, it was oriented towards eliminating all kinds of privileges based on the differences between the city and the village, intellectual and physical labour and workers and peasants. In many ways it was taking the radical direction. There was precedence the implementation of socialist education in the Soviet Union which adopted more or less capitalistic form of system because it focused on gaining knowledge, degree and certificate as the measurement of qualification. But China practised the pedagogy which was more open, more flexible and more varied and experimental. It did not take closed class rooms the formal degrees, certificates and as the only criteria of being educated. In teaching and learning practice, experiment and political orientation were major things to emphasize. It used people who have fresh experience as teachers although man power with certificates and bookish knowledge were not ignored. Schools and classrooms were not only places to learn and gain knowledge. Every agricultural field, every workshop, every factory was the place of education. These practices were new and trail based. In other words it refused to follow the beaten track and attempted to undertake the adventure into the unexplored territory.

Every form of education contains ideological and political content. Under capitalism such content does not have to be overtly stated because is implicated in every particle of social practices and education is seen as devoid of political content. Since socialism is a radical rupture from the existing form of value systems, its ideology has to be openly advocated and its contents are overtly political. During Cultural Revolution, individual interests and progress were subordinated to collective interests. The main purpose of the system of education of that period was to produce man power which had expertise with proletarian outlook and culture. Education was not confined to classrooms and libraries and it was not a prerogative of academic authorities. It was an instrument of the socialist transformation of the whole society in which every member was taken as potential teacher and learner.

\section{REFERENCES}

1. Aggarwal, J.C. (1995). Theory and Principle of Education. New Delhi: Vikas Publishing House PVT. LTD.

2. Beijing Review. (1981, No. 27). "Questions of Party History.” (10-39). p.22.

3. Beijing Review. (1981, No. 46). “Academic Degrees.” (7-8). p.8.

4. Chiao, W. (1975). “July 21 Workers' College.” Peking Review. No. 37. (16-20). pp 17, 19.

5. Dongping H. (2000). The Unknown Cultural Revolution: Educational Reforms and their Impact on China's Rural Development. NY: Garland Publishing, Inc. www. wengewang.org.

6. Engels F. and Karl Marx. (1977). Selected Works. Vol. One. Moscow: Progress Publishers.

7. Lee C. and et al. (2020). "Influences of the Cultural Revolution on the education and wages of today's Chinese laborers.” Economic Research-Ekonomaska Istrazivanja. 2020, Vo. 33 issue 1 https:/dol.org/10.1080/ 
8. Mao T. (1958) "Red and Expert." Selected Works of Mao Tsetung, Vol. VIII https://www.marxists.org/referencelarchive/mao/selected-works/volume-8/index.htm,

9. Mao T. (1971) Selected Readings from the Works of Mao Tsetung. Peking: Foreign Language Press.

10. Mao T. (1977). Selected Works of Mao Tsetung Volume. V. Peking: Foreign Language Press.

11. Marx, K. and Frederick Engels. (1977). Selected Works. Vol. One. Moscow: Progress Publishers.

12. Peking Review. (1966, No 33). "Decision of C.P.C. Central Committee Concerning the Great Proletarian Cultural Revolution” (6-10). pp. 6, 8, 10.

13. Peking Review. (1967, No. 47). “Some Tentative Programmes for Revolutionizing Education.” (9-11). p. 11.

14. Peking Review. (1068, No 7). 1969, “A School Managed by Workers and Linked Up With a People’s Commune and a P.L.A. Unit" (3-7) p.3.

15. Peking Review. (1969, No.14). “Tsinghua University's Intellectuals Advance Along The Road of Revolutionization” $(10-$ 14). p.11.

16. Peking Review. (1969, No. 39.) "Chairman Mao on Continuing the Revolution under the Dictatorship of the Proletariat." (3-10). p. 9.

17. Peking Review. (1970, No.39). "In the Great Proletarian Cultural Revolution a most Important Task is to Transform Old Educational System and the Old Principles and Methods of Teaching." (14-17+21). p.14.

18. Peking Review. (1970, No. 40). "The Wishes of Workers, Peasants and Soldiers in Their Hundreds of Millions Have Come True!" (6-8). p.6

19. Peking Review (1971, No. 4). “Workers -Teachers in Tinghua University.” (7-9). p.7

20. Peking Review. (1971, No. 35). “Tent Schools on Tibetan Pleauto.” p. 27.

21. Peking Review. (1972, No. 10). “New Semester at Central Institute for Nationalities.” p.4.

22. Peking Review. (1972, No. 14). “Mass Physical Training." (10-14). p. 13.

23. Peking Review. (1972, No. 19). “The May 7 Cadre School.” (5-7). p. 5.

24. Peking Review. (1973, No. 8). “Enlivening Studies and Accentuating Student Initiative.” (10-13), pp.10, 11, 12.

25. Peking Review. (1973, No. 9). “New Type of University Students.” (15-18). p. 15.

26. Peking Review. (1973, No. 23). "Spare time Night Schools for Peasants." (18-19+21). p. 18.

27. Peking Review. (1974, No. 31). “A Good Way to Settle Educated Youth In the Countryside.” (13-15). p. 13.

28. Peking Review. (1975, No. 6). “Ten Million School Graduates Go to the Countryside.” p.5.

29. Peking Review. (1975, No. 7). “Peasants-College Students-Peasants. ” (13-15). p. 13.

30. Peking Review. (1976, No. 2). “Twelve Million School Graduates Settle in the Countryside.” (10-13). p.12.

31. Peking Review. (1976, No. 10). "Fundamental Differences Between the Two Lines in Education” (6-11). pp. 6, 9.

32. Saywell, G. W. (1980). “Education in China Since Mao.” The Canadian Journal of Education, Vol. 10, No.1. (1-27). pp. 4, 5.

33. Shih-yi, C. (1976). “An Example of Open-Door Education.” Peking Review. No. 1. (14-18).p.16. wg.1966.com.

34. Xuan, X. (1981). "Why Should a Theory Be Discarded?” Beijing Review. No.44. (20-29). pp 20 , 22. 

